\title{
Effect of Expanded Perlite Aggregate Size on Physical and Mechanical Properties of Ultra Lightweight Concrete Produced with Expanded Perlite Aggregate
}

\author{
Mucip Tapan ${ }^{1 *}$, Celil Engin ${ }^{1}$ \\ ${ }^{1}$ Department of Civil Engineering, Faculty of Engineering, Van Yüzüncü Yıl University, \\ Zeve Kampüsü, 65080, Tuşba, Van, Turkey \\ ${ }^{*}$ Corresponding author, e-mail: mtapan@yyu.edu.tr
}

Received: 12 June 2018, Accepted: 03 July 2019, Published online: 14 August 2019

\begin{abstract}
In this study, ultra-light weight concrete (ULWC) with heat-insulating properties is produced by using different size expanded perlite aggregates and various admixtures. The compressive strength, 4 point bending strength, freezing and thawing resistance, water absorption, dry unit weight, ultra sound velocities and thermal conductivity of the samples were determined by applying appropriate tests. The effect of different size expanded perlite aggregate on the properties of ULWC were also investigated in this study and it was found that as the expanded perlite aggregate diameter increased, the void volume uniformity, water absorption percentage and freezing-thawing resistance increased while the unit volume weight of ULWC samples, ultrasound speed velocities, thermal conductivity and compressive strength were decreased. The changes in the masses and compressive strength of ULWC samples subjected to freezing and thawing cycles were examined. The compressive strength loss was found to be between $5 \%$ and $47 \%$ while the weight loss was between $1 \%$ and $3.5 \%$ after 15 freezing and thawing cycles. Finally, the effects of the admixtures on the fresh properties of ULWC were examined and it was determined that the use of $4.5 \mathrm{~kg}$ of air-entraining material in one cubic meter of concrete mix is the most ideal ratio and the use of more than $0.01 \%$ by volume of polypropylene fiber is caused settlements in fresh concrete mixtures.
\end{abstract}

\section{Keywords}

expanded perlite, thermal conductivity, mechanical and physical properties, ultra lightweight concrete

\section{Introduction}

Lightweight concrete, which has superior properties compared to normal concrete in terms of heat insulation and unit volume weight, is now being used more and more $[1,2]$. In addition to reducing the loads on reinforced concrete structures, the preference for more advanced materials in terms of fire resistance, sound and heat insulation properties is increasing. This leads to increased interest and widespread use of lightweight concrete [3]. Depending on the properties of the thermal insulation materials used in the construction and the general condition of the construction, it is known that energy savings of 25 to $65 \%$ can be achieved in heat-insulated structures [3].

The expanded perlite aggregate is a natural volcanic rock, which is being widely used in the world $[4,5]$. The perlite removed as rock is classified by separating it into various dimensions after it is crushed. When this classified perlite is heated to $850-1150^{\circ} \mathrm{C}$, it loses its water content and explodes under the effect of temperature. With this explosion, sizes of the crushed perlite aggregate increases up to 35 times of its original volume. The material subjected to these processes takes the name of expanded perlite. The expanded perlite is white in color with a melting point of $1300{ }^{\circ} \mathrm{C}$. Its density varies between $32-200 \mathrm{~kg} / \mathrm{m}^{3}$ whereas its thermal conductivity is between $0.040-0.055$ $\mathrm{W} / \mathrm{mK}$ [6]. Because of these properties, it is widely used as an insulating material.

In the light of previous research [7-9], state-of-the-art methodologies were used to produce cement based inorganic insulation materials with minimum unit weight and maximum heat insulation. From this perspective, the insulation material was composed of three main materials (aggregate, cement matrix and admixtures). Each material was designed to have maximum heat insulation capacity by itself. The expanded perlite aggregates that have superior characteristics in terms of heat insulation were used to develop the composite insulation material. Since, 
expanded perlite aggregate can be found in different sizes, it is important to find the effect of expanded perlite aggregate size on the mechanical and physical properties of ultra lightweight concrete samples. Therefore, within the scope of this study, the mechanical and physical properties of ultra lightweight concrete samples produced with different size expanded perlite aggregates were determined in order to achieve the best insulation property.

\section{Materials and method}

\subsection{Materials}

The particle size distribution of the expanded perlite aggregates varies depending on their origin and grinding conditions. The practical particle size of expanded perlite aggregates used in this study are; $0.3,1.18,2$ and $3.6 \mathrm{~mm}$ (Fig. 1). The mechanical and physical properties of these expanded perlite aggregates are given in Table 1 . The chemical, physical and mechanical properties of CEM I $52.5 \mathrm{R}$ white type cement given in Table 2 was used as the binder. The water from the Van city drinking water network was used as the mixing water.

It is a well known fact that fiber reinforced concrete has greater energy-absorbing ability, than normal concrete. Ultra lightweight concrete containing fiber has a promising future for producing different types of building insulation materials since it reduces the formation of plastic shrinkage and improves the durability and toughness of concrete [10, 11]. Therefore, Polypropylene (PP) fibers shown in Fig. 2, is used in this study. The physical and mechanical properties of the Polypropylene fibers used are given in Table 3. A commercially available air entraining admixture is used to reduce the dry unit volume weight of ultra lightweight concretes by providing air bubbles inside the concrete. Copolymer dispersion-based concrete admixture is used as a concrete strengthening agent and as a dust reducing agent. The physical properties of the copolymer dispersion-based concrete admixture are given in Table 4.

\subsection{Method}

\subsubsection{Experimental design of ultra lightweight} concretes produced with expanded perlite aggregates Firstly, ultra lightweight concrete samples were prepared at different unit weights using the P05 expanded perlite aggregate, that has a particle size of $1.18 \mathrm{~mm}$. Secondly, based on the results of experiments conducted with $\mathrm{P} 05$ expanded perlite aggregate, the effects of different size expanded perlite aggregates (P2 (<300 micron), P05 (1.18 mm), P12 (2 mm) and P14 $(3.6 \mathrm{~mm}))$ on the properties of ultra lightweight concrete were investigated and an optimum aggregate gradation was developed. The design method of the ultra lightweight concrete produced in this study is given in Table 5 .

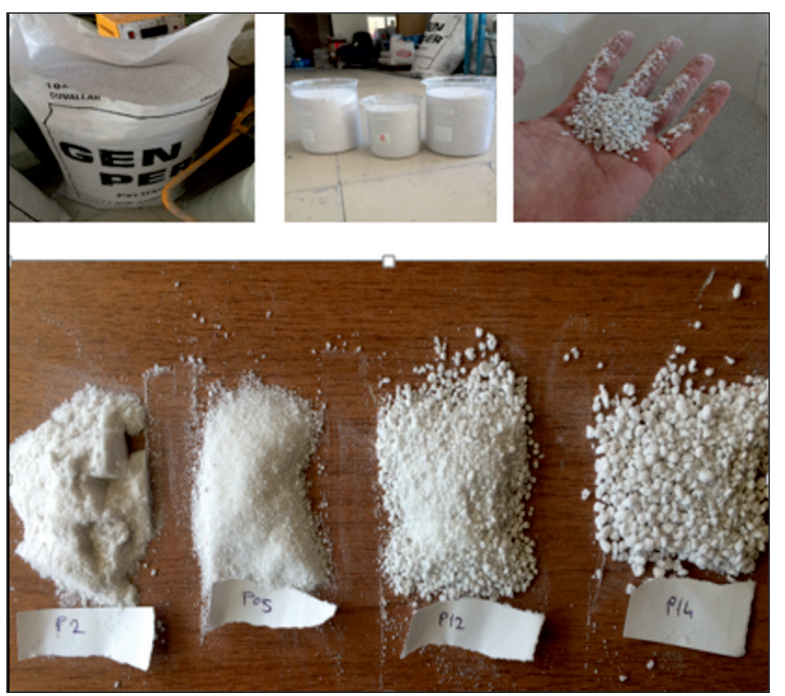

Fig. 1 Different size expanded perlite aggregates used in this study

Table 1 Chemical composition and some of the physical properties of different size expanded perlite aggregates used in this study

\begin{tabular}{|c|c|c|c|c|}
\hline Chemical Composition & $\begin{array}{c}\text { P05 } \\
\text { (Aggregate Size) } \\
(1.18 \mathrm{~mm})\end{array}$ & $\begin{array}{c}\mathrm{P} 0, \mathrm{P} 1, \mathrm{P} 2 \\
\text { (Aggregate Size) } \\
(<300 \text { micron) }\end{array}$ & $\begin{array}{c}\text { P12 (Aggregate Size) } \\
(2 \mathrm{~mm})\end{array}$ & $\begin{array}{c}\text { P14 (Aggregate Size) } \\
(3.6 \mathrm{~mm})\end{array}$ \\
\hline $\mathrm{SiO}_{2}$ & 72.4 & 73.5 & 72.5 & 72.9 \\
\hline $\mathrm{Al}_{2} \mathrm{O}_{3}$ & 13.5 & 12.4 & 12.9 & 13.4 \\
\hline $\mathrm{K}_{2} \mathrm{O}$ & 5.54 & 5.12 & 5.35 & 5.24 \\
\hline $\mathrm{Na}_{2} \mathrm{O}$ & 3.4 & 3.61 & 3.54 & 3.15 \\
\hline $\mathrm{MgO}$ & 0.16 & 0.14 & 0.14 & 0.15 \\
\hline $\mathrm{CaO}$ & 0.9 & 0.87 & 0.9 & 0.89 \\
\hline $\mathrm{Fe}_{2} \mathrm{O}_{3}$ & 0.76 & 0.64 & 0.66 & 0.74 \\
\hline $\mathrm{TiO}_{2}$ & 0.09 & 0.09 & 0.09 & 0.09 \\
\hline Loss of ignition & 3.25 & 3.65 & 3.92 & 3.44 \\
\hline Dry unit weight $\left(\mathrm{kg} / \mathrm{m}^{3}\right)$ & 45 & 110 & 55 & 75 \\
\hline
\end{tabular}


Table 2 The physical and chemical properties of cement used in this

\begin{tabular}{|c|c|}
\hline Chemical Composition & CEM-I $52.5 \mathrm{R}$ \\
\hline $\mathrm{CaO}$ & 65.70 \\
\hline $\mathrm{SiO}_{2}$ & 21.60 \\
\hline $\mathrm{Al}_{2} \mathrm{O}_{3}$ & 4.05 \\
\hline $\mathrm{Fe}_{2} \mathrm{O}_{3}$ & 0,26 \\
\hline $\mathrm{MgO}$ & 1.30 \\
\hline $\mathrm{SO}_{3}$ & 3.30 \\
\hline $\mathrm{K}_{2} \mathrm{O}$ & 0.35 \\
\hline $\mathrm{Na}_{2} \mathrm{O}$ & 0.32 \\
\hline $\mathrm{TiO}_{2}$ & 0.33 \\
\hline Loss on ignition & 2.79 \\
\hline $\mathrm{SiO}_{2}+\mathrm{Al}_{2} \mathrm{O}_{3}+\mathrm{Fe}_{2} \mathrm{O}_{3}$ & 25.91 \\
\hline Density $\left(\mathrm{g} / \mathrm{cm}^{3}\right)$ & 3.06 \\
\hline Blaine Fineness $(\mathrm{cm} 2 / \mathrm{s})$ & 4600 \\
\hline Volume Expansion (mm) & 1.00 \\
\hline Size $>90 \mu \mathrm{m}(\%)$ & 5.18 \\
\hline Size $>45 \mu \mathrm{m}(\%)$ & 22.22 \\
\hline
\end{tabular}

Table 3 Physical and mechanical properties of polypropylene fibers

\begin{tabular}{lccc}
\hline $\begin{array}{l}\text { Diameter } \\
(\mu \mathrm{m})\end{array}$ & $\begin{array}{c}\text { Length } \\
(\mathrm{mm})\end{array}$ & $\begin{array}{c}\text { Tensile Strength } \\
(\mathrm{MPa})\end{array}$ & $\begin{array}{c}\text { Modulus of Elasticity } \\
(\mathrm{GPa})\end{array}$ \\
\hline 20 & $12-14$ & 684 & 3.7 \\
\hline
\end{tabular}

Table 4 Physical properties of copolymer dispersion-based concrete admixture

\begin{tabular}{lc}
\hline Structure & Modified polymer dispersion \\
\hline Color & White \\
Density & $1.1 \mathrm{~kg} / \mathrm{m}^{3}$ \\
$\mathrm{pH}$ & 8.5 \\
Application temperature & $+5 \mathrm{C}-+35 \mathrm{C}$ \\
\hline
\end{tabular}
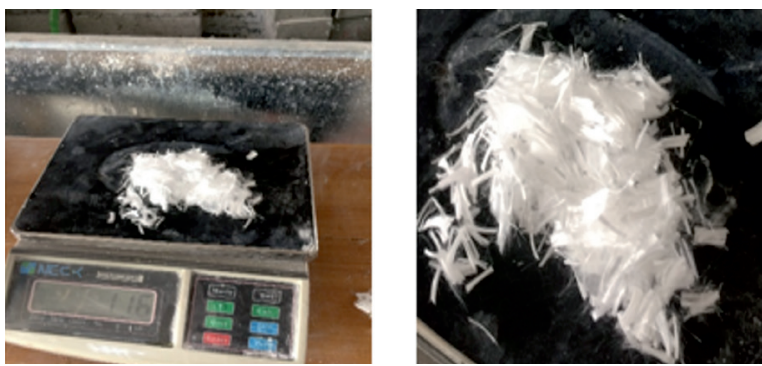

Fig. 2 Polypropylene Fibers used in this study
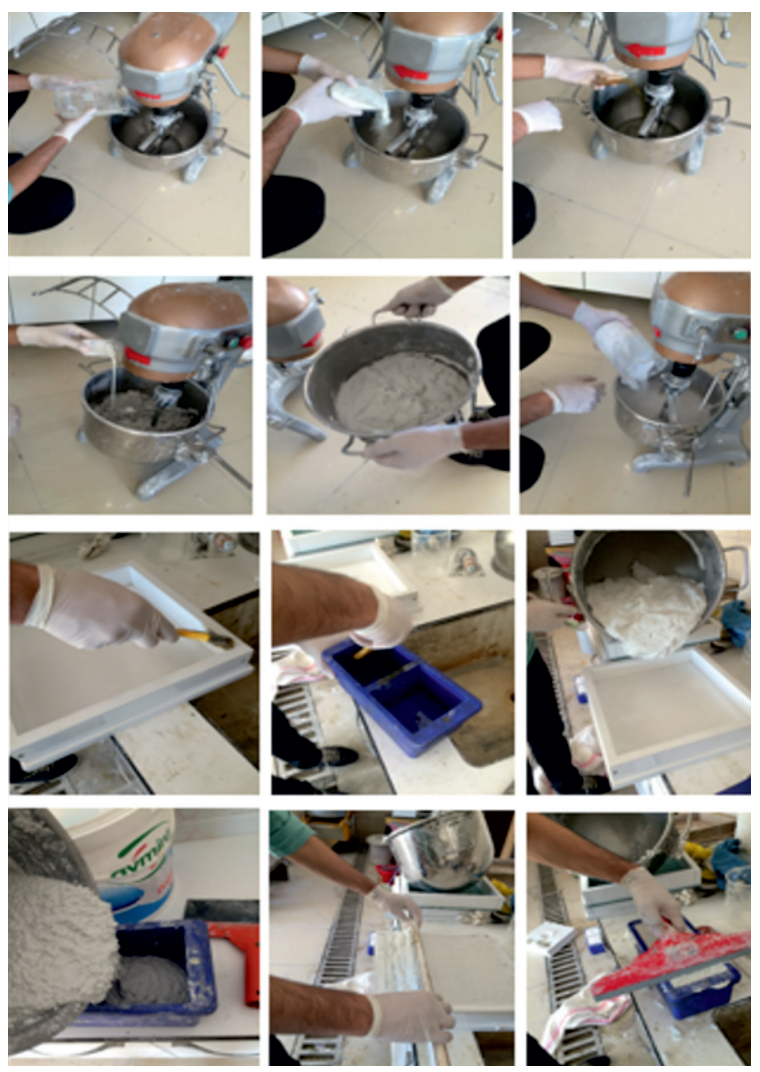

Fig. 3 Production of ultra lightweight concrete samples using expanded perlite aggregates

Table 5 The design of ultra lightweight concrete experiments

\begin{tabular}{|c|c|}
\hline Experiment Number & The method used in experiments (Trial and Error Method) \\
\hline 1 & First experiment was carried out to investigate the fresh concrete workability for constant W/C ratio $(\mathrm{W} / \mathrm{C}=2.5)$. \\
\hline $2-7$ & $\begin{array}{l}\text { These experiments were conducted to determine the effect of the amount of air entraining additive on the physical and } \\
\text { mechanical properties of produced ultra lightweight concretes (All other materials in the mixture were kept constant and } \\
\text { the copolymer dispersion-based admixture was not used). }\end{array}$ \\
\hline $8-13$ & $\begin{array}{l}\text { These experiments were conducted to determine the effects of the ratio of copolymer dispersion-based admixture and air } \\
\text { entraining admixture on the properties of ultra lightweight concrete samples produced in this study. }\end{array}$ \\
\hline $14-20$ & $\begin{array}{c}\text { The effect of W/C ratio as well as amount of air entraining admixture on the dry unit weight of ultra lightweight concrete } \\
\text { samples was determined by these experiments. }\end{array}$ \\
\hline $21-32$ & $\begin{array}{l}\text { These experiments were conducted to determine the effect of different size expanded perlite aggregates (P2, P05, P12 and } \\
\qquad \mathrm{P} 14) \text { and their gradation on the properties of ultra lightweight concretes. }\end{array}$ \\
\hline $32-38$ & $\begin{array}{l}\text { The effect of the amount of polypropylene fibers on the properties of fresh and hardened ultra lightweight concretes were } \\
\text { determined with these experiments. }\end{array}$ \\
\hline
\end{tabular}




\subsubsection{Preparation of ultra lightweight concrete samples using expanded perlite aggregates}

Ultra lightweight concrete specimens with different size expanded perlite aggregates were prepared in five stages as shown in Fig 3. First, the mixing water and cement binder material was poured into the mixer bowl and then mixed. After the cement is fully dispersed in the mixing water, the air entraining admixture is added to the mix for reducing the unit weight.

The air entraining admixture was mixed at high speed and stirred for at least 2 minutes to form air bubbles. As the air-entraining admixture showed its effect fully, the expanded perlite aggregate was slowly poured into the mix. When the desired concrete mix consistency obtained, the copolymer dispersion-based admixture was poured into the mix and the mixture was mixed for at least 2 minutes in order to fully disperse the copolymer dispersion-based admixture. In ultra lightweight concrete specimens produced with fibers, the concrete mix was prepared as defined above and after mixing of copolymer dispersion-based admixture the fibers are added to the fresh mix and the mixture was mixed for 5 minutes with a high speed mixer in order to homogeneously distribute the fibers within the mix.

Finally, the fresh concrete mixtures were poured into molds $(10 \times 10 \times 10 \mathrm{~cm} ; 30 \times 30 \times 5 \mathrm{~cm} ; 10 \times 10 \times 40 \mathrm{~cm})$ for mechanical and physical tests. Mix designs of ultra lightweight concrete specimens produced within the scope of this study are given in Table 6 and Table 7.

\subsubsection{Tests conducted on the ultra lightweight concrete specimens}

The unit weight and water absorption of ultra lightweight concrete specimens were determined according to ASTM C642 [12] standard (Fig. 4 and Fig. 5). The flexural and compressive strength of ultra lightweight concrete specimens were determined according to ASTM C495 [13] and ASTM C78 [14], respectively (Fig. 6 and Fig. 7). Prismatic testing specimens with the dimensions of $100 \times 100 \times 100 \mathrm{~mm}$ for all of these tests except for flexural strength test in which $100 \times 100 \times 400 \mathrm{~mm}$ specimens were used.

The freezing and thawing resistance of the ultra lightweight concrete specimens is one of the main parameters that defines its durability. Therefore, freezing and thawing test following the procedures prescribed in national TS EN 15304 [15] standard was conducted (Fig. 8).

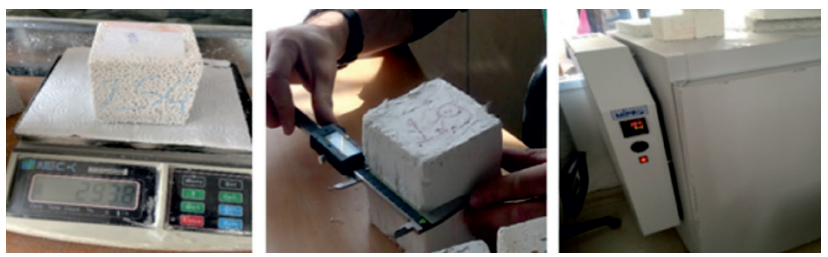

Fig. 4 Determination of dry unit weight of ultra lightweight concrete specimens

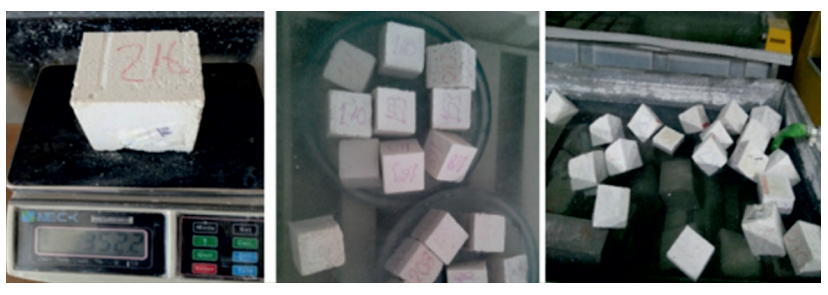

Fig. 5 Tests conducted to determine water absorption of ultra lightweight concrete specimens
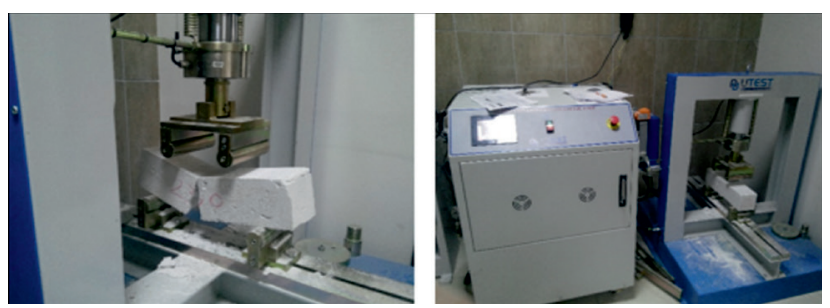

Fig. 6 Tests conducted to determine flexural strength of ultra lightweight concrete specimens
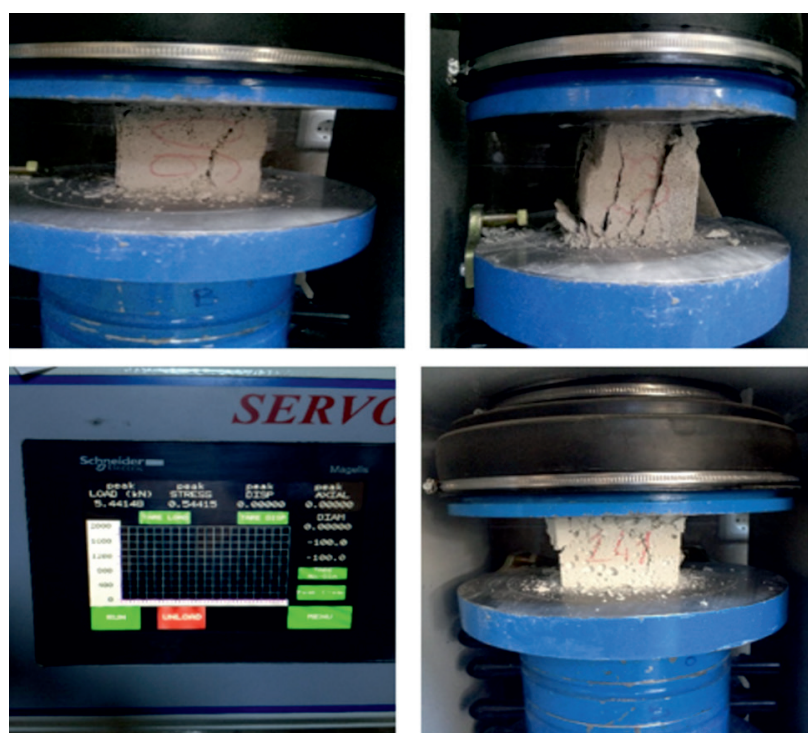

Fig. 7 Tests conducted to determine compressive strength of ultra lightweight concrete specimens

Finally, the thermal conductivity of the ultra lightweight concrete specimens developed in this study was determined following the procedures in TS EN 12667 [16] using thermal conductivity testing machine (Fig. 9). 
Table 6 Mix design and dry unit weight of ultra lightweight concrete specimens produced with P05 aggregate

\begin{tabular}{|c|c|c|c|c|c|c|c|}
\hline $\begin{array}{l}\text { Specimen } \\
\text { Number }\end{array}$ & $\begin{array}{l}\text { Cement } \\
\left(\mathrm{kg} / \mathrm{m}^{3}\right)\end{array}$ & $\begin{array}{l}\text { Water } \\
\left.\left(\mathrm{kg} / \mathrm{m}^{3}\right)\right)\end{array}$ & $\begin{array}{l}\text { Expanded Perlite } \\
\left.\qquad\left(\mathrm{kg} / \mathrm{m}^{3}\right)\right)\end{array}$ & $\begin{array}{l}\text { Air entraining admixture } \\
\left.\qquad\left(\mathrm{kg} / \mathrm{m}^{3}\right)\right)\end{array}$ & $\begin{array}{l}\text { Copolymer dispersion-based } \\
\text { admixture }\left(\mathrm{kg} / \mathrm{m}^{3}\right)\end{array}$ & $\mathrm{W} / \mathrm{C}$ & DUW $\left(\mathrm{kg} / \mathrm{m}^{3}\right)$ \\
\hline 1 & 112.1 & 280.3 & 52.7 & 22.4 & 11.2 & 2.5 & 257.0 \\
\hline 2 & 204.2 & 510.5 & 96.0 & 0 & 0 & 2.5 & 468.0 \\
\hline 3 & 83.3 & 208.3 & 39.2 & 2.1 & 0 & 2.5 & 191.0 \\
\hline 4 & 90.3 & 225.8 & 42.4 & 4.5 & 0 & 2.5 & 207.0 \\
\hline 5 & 89.9 & 224.7 & 42.2 & 6.7 & 0 & 2.5 & 206.0 \\
\hline 6 & 74.2 & 185.4 & 34.9 & 7.4 & 0 & 2.5 & 170.0 \\
\hline 7 & 65.4 & 163.6 & 30.8 & 13.1 & 0 & 2.5 & 150.0 \\
\hline 8 & 146.2 & 365.4 & 68.7 & 3.7 & 7.3 & 2.5 & 335.0 \\
\hline 9 & 143.1 & 357.8 & 67.3 & 3.7 & 7.2 & 2.5 & 328.0 \\
\hline 10 & 71.6 & 178.9 & 33.6 & 14.3 & 3.6 & 2.5 & 164.0 \\
\hline 11 & 277.8 & 694.4 & 130.6 & 6.9 & 27.8 & 2.5 & 382.0 \\
\hline 12 & 116.5 & 291.2 & 54.8 & 5.8 & 11.6 & 2.5 & 267.0 \\
\hline 13 & 102.1 & 255.2 & 48.0 & 10.2 & 10.2 & 2.5 & 234.0 \\
\hline 14 & 199.4 & 299.1 & 93.7 & 39.9 & 19.9 & 1.5 & 457.0 \\
\hline 15 & 157.1 & 235.6 & 73.8 & 31.4 & 15.7 & 1.5 & 360.0 \\
\hline 16 & 207.2 & 310.0 & 97.4 & 41.4 & 20.7 & 1.5 & 475.0 \\
\hline 17 & 168.4 & 336.8 & 79.2 & 4.2 & 16.8 & 2.0 & 386.0 \\
\hline 18 & 116.1 & 232.1 & 54.5 & 5.8 & 11.6 & 2.0 & 266.0 \\
\hline 19 & 157.5 & 236.3 & 74.0 & 3.9 & 15.8 & 1.5 & 361.0 \\
\hline 20 & 170.2 & 425.4 & 80.0 & 8.5 & 17.0 & 2.5 & 390.0 \\
\hline
\end{tabular}

Table 7 Mix design and dry unit weight of ultra lightweight concrete specimens produced with different size expanded perlite aggregates

\begin{tabular}{|c|c|c|c|c|c|c|c|c|c|c|}
\hline $\begin{array}{l}\text { Specimen } \\
\text { Number }\end{array}$ & $\begin{array}{l}\text { Cement } \\
\left(\mathrm{kg} / \mathrm{m}^{3}\right)\end{array}$ & $\begin{array}{c}\text { Water } \\
\left(\mathrm{kg} / \mathrm{m}^{3}\right)\end{array}$ & $\begin{array}{l}\text { Air entraining } \\
\text { admixture } \\
\left(\mathrm{kg} / \mathrm{m}^{3}\right)\end{array}$ & $\begin{array}{c}\text { Copolymer } \\
\text { dispersion-based admixture } \\
\left(\mathrm{kg} / \mathrm{m}^{3}\right)\end{array}$ & $\begin{array}{c}\mathrm{P} 05 \\
\left(\mathrm{~kg} / \mathrm{m}^{3}\right)\end{array}$ & $\begin{array}{c}\mathrm{P} 2 \\
\left(\mathrm{~kg} / \mathrm{m}^{3}\right)\end{array}$ & $\begin{array}{c}\mathrm{P} 12 \\
\left(\mathrm{~kg} / \mathrm{m}^{3}\right)\end{array}$ & $\begin{array}{c}\mathrm{P} 14 \\
\left(\mathrm{~kg} / \mathrm{m}^{3}\right)\end{array}$ & $\begin{array}{c}\text { PP Fiber } \\
\left(\mathrm{kg} / \mathrm{m}^{3}\right)\end{array}$ & $\begin{array}{c}\text { PP Fiber } \\
(\% \mathrm{~V})\end{array}$ \\
\hline 21 & 142.9 & 357.1 & 7.1 & 13.0 & 0.0 & 0.0 & 0.0 & 107.14 & 0.0 & 0 \\
\hline 22 & 142.9 & 357.1 & 7.1 & 13.0 & 0.0 & 0.0 & 78.57 & 0.0 & 0.0 & 0 \\
\hline 23 & 131.6 & 328.9 & 6.6 & 12.0 & 0.0 & 0.0 & 36.18 & 49.34 & 0.0 & 0 \\
\hline 24 & 142.9 & 357.1 & 7.1 & 13.0 & 0.0 & 78.57 & 0.0 & 53.57 & 0.0 & 0 \\
\hline 25 & 142.9 & 357.1 & 7.1 & 13.0 & 32.14 & 0.0 & 0.0 & 53.57 & 0.0 & 0 \\
\hline 26 & 125.0 & 312.5 & 6.3 & 11.4 & 14.06 & 34.37 & 17.18 & 23.43 & 0.0 & 0 \\
\hline 27 & 142.9 & 357.1 & 7.1 & 13.0 & 16.06 & 39.28 & 0.0 & 53.57 & 0.0 & 0 \\
\hline 28 & 142.9 & 357.1 & 7.1 & 13.0 & 16.06 & 0.0 & 0.0 & 80.35 & 0.0 & 0 \\
\hline 29 & 131.6 & 328.9 & 6.6 & 12.0 & 14.80 & 0.0 & 54.27 & 0.0 & 0.0 & 0 \\
\hline 30 & 131.6 & 328.9 & 6.6 & 12.0 & 5.92 & 0.0 & 21.70 & 59.21 & 0.0 & 0 \\
\hline 31 & 131.6 & 328.9 & 6.6 & 12.0 & 11.80 & 0.0 & 21.70 & 49.34 & 0.0 & 0 \\
\hline 32 & 131.6 & 328.9 & 6.6 & 12.0 & 17.76 & 0.0 & 21.70 & 39.47 & 0.0 & 0 \\
\hline 33 & 131.6 & 328.9 & 6.6 & 12.0 & 0.0 & 0.0 & 36.18 & 49.34 & 1.32 & 0.140 \\
\hline 34 & 131.6 & 328.9 & 6.6 & 12.0 & 0.0 & 0.0 & 36.18 & 49.34 & 0.28 & 0.033 \\
\hline 35 & 131.6 & 328.9 & 6.6 & 12.0 & 0.0 & 0.0 & 36.18 & 49.34 & 0.55 & 0.066 \\
\hline 36 & 131.6 & 328.9 & 6.6 & 12.0 & 0.0 & 0.0 & 36.18 & 49.34 & 0.83 & 0.100 \\
\hline 37 & 131.6 & 328.9 & 6.6 & 12.0 & 0.0 & 0.0 & 36.18 & 49.34 & 0.09 & 0.010 \\
\hline 38 & 131.6 & 328.9 & 6.6 & 12.0 & 0.0 & 0.0 & 36.18 & 49.34 & 0.20 & 0.020 \\
\hline
\end{tabular}



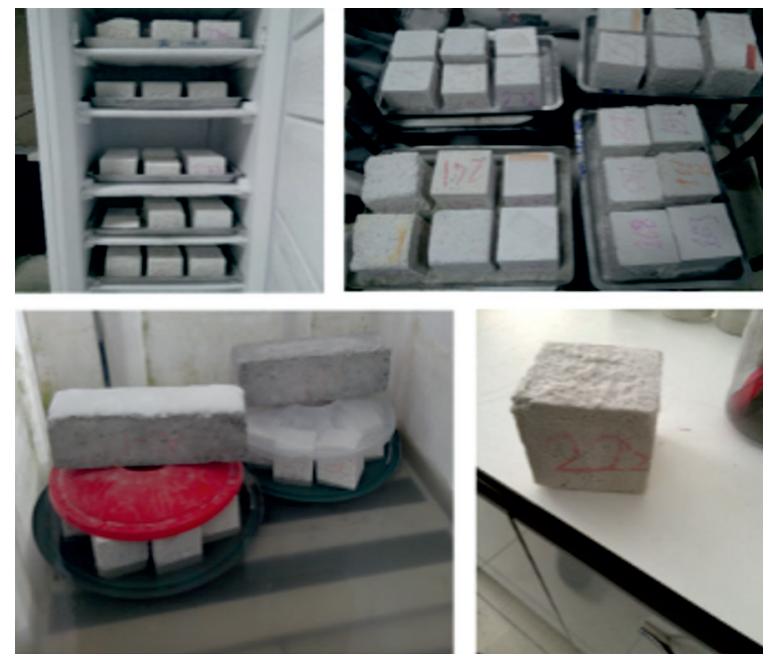

Fig. 8 Freezing and thawing tests of ultra lightweight concrete specimens
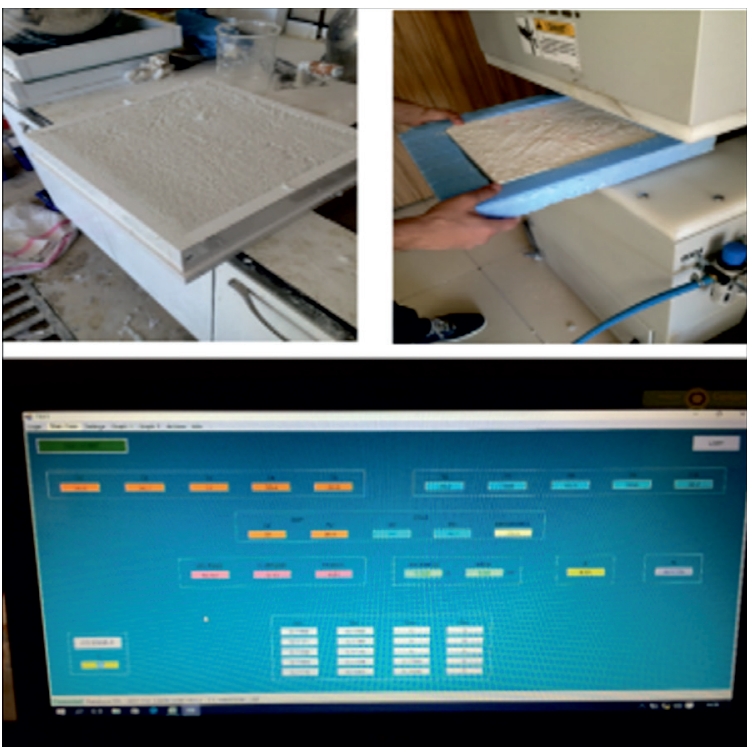

Fig. 9 Thermal conductivity tests of ultra lightweight concrete specimens

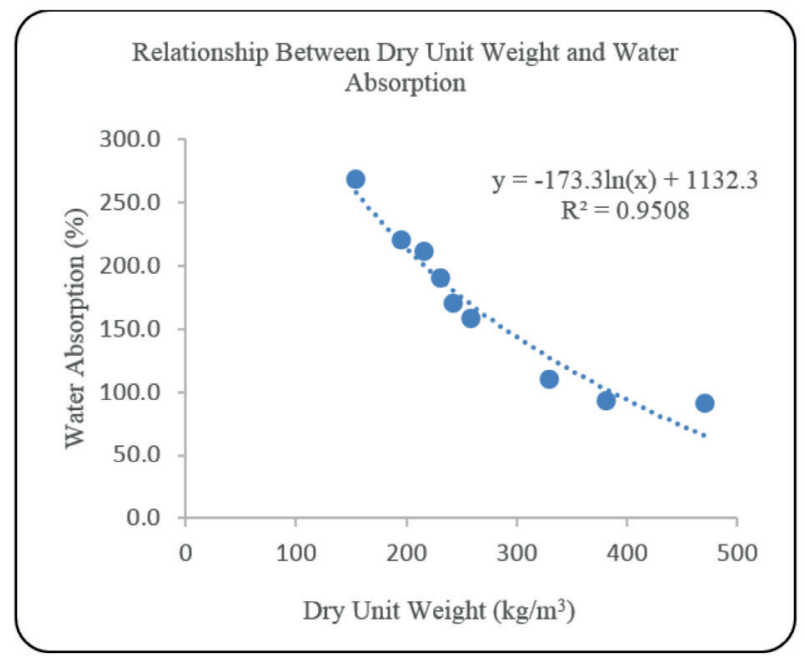

Fig. 10 The relationship between dry unit weight and water absorption characteristics of ULWC specimens produced with P05 aggregate

\section{Results and discussion}

The experimental test results of ultra lightweight concrete samples prepared at different unit weights using the expanded perlite aggregate, named P05 that has a particle size of $1.18 \mathrm{~mm}$, is given in Table 8 whereas the experimental results of concrete specimens prepared with different size expanded perlite aggregates (P2 (< 300 micron), P05 (1.18 mm), P12 (2 mm) and P14 (3.6 mm)) are given in Table 9. As shown in Table 8 and Table 9, the unit weight of concrete can be reduced substantially by using expanded perlite aggregates. Weight reduction of concrete elements that leads to reduction of the total weight of the building results in reduced cross sections and less amount of reinforcement which is important for economical aspects.

\subsection{Influence of dry unit weight of ULWC specimens on water absorption characteristics}

The relationship between the dry unit volume weights of the samples and the water absorption percentages is given in Fig. 10. The rate of water absorption was found to be higher due to the high void ratio in the samples with less unit weight. By increasing the expanded perlite aggregate content, the total porosity of the concrete, which is reflected by the reduction of the unit weight of the concrete samples, is also increased and resulted in higher water absorption. A significant relationship between the water absorption percentages of the test samples and the dry unit volume weight was observed. It is seen that the approximate value of the water absorption percentage of the samples with known dry unit volume weight can be determined by using this empirical formula obtained from this relationship and shown on the graph (for dry unit volume range of $150 \mathrm{~kg} / \mathrm{m}^{3}-468 \mathrm{~kg} / \mathrm{m}^{3}$ ).

\subsection{The relationship between dry unit weight and compressive strength of ULWC specimens produced with $\mathrm{P05}$ aggregate}

Regardless of the mix design, the compressive strength of the concrete samples decrease with a decrease in unit weight of concrete specimens, which can be attributed to the high content of air in the expanded perlite aggregates. The relationship between the dry unit weight and the compressive strength of the ultra lightweight concrete specimens with heat insulation properties are given in Fig 11. Although a significant relationship between the dry unit weights and the compressive strength cannot be observed (i.e. $\mathrm{R}^{2}=0.6932$ ), the compressive strength increases as the dry unit weight of the specimens increases due to the fact that the void ratio decreases as the dry unit weight of the specimen increases. 
Table 8 Test results of ultra lightweight concrete specimens produced with P05 aggregate

\begin{tabular}{|c|c|c|c|c|c|c|c|}
\hline $\begin{array}{l}\text { Experiment } \\
\text { Number }\end{array}$ & $\begin{array}{c}\text { Compressive } \\
\text { Strength }(\mathrm{MPa})\end{array}$ & $\begin{array}{c}\text { Dry Unit } \\
\text { Weight }\left(\mathrm{kg} / \mathrm{m}^{3}\right)\end{array}$ & $\begin{array}{l}\text { Ultrasonic Pulse } \\
\text { Velocity }(\mathrm{m} / \mathrm{s})\end{array}$ & $\begin{array}{c}\text { Flexural } \\
\text { Strength (MPa) }\end{array}$ & $\begin{array}{l}\text { Thermal Conductivity } \\
\qquad(\mathrm{W} / \mathrm{mK})\end{array}$ & $\begin{array}{c}\text { Water } \\
\text { Absorption (\%) }\end{array}$ & $\begin{array}{c}\text { Freeze-Thaw } \\
\text { Resistance }\end{array}$ \\
\hline 1 & 0.38 & 257.0 & 936.0 & 0.045 & 0.064 & 267.7 & Adequate \\
\hline 2 & 0.87 & 468.0 & 1756.0 & 0.450 & 0.120 & 76.9 & Adequate \\
\hline 3 & 0.15 & 191.0 & 1112.0 & 0.114 & 0.056 & 189.2 & Inadequate \\
\hline 4 & 0.20 & 207.0 & 914.0 & 0.018 & 0.059 & 219.9 & Adequate \\
\hline 5 & 0.26 & 206.0 & 930.22 & 0.066 & 0.059 & 213.2 & Adequate \\
\hline 6 & 0.30 & 170.0 & 855.49 & 0.039 & 0.041 & 231.9 & Adequate \\
\hline 7 & 0.13 & 150.0 & 791.76 & 0.024 & 0.039 & 242.3 & Adequate \\
\hline 8 & 0.50 & 335.0 & 1462.0 & 0.300 & 0.083 & 109.7 & Adequate \\
\hline 9 & 0.50 & 328.0 & 1244.0 & 0.066 & 0.083 & 211.1 & Başarısız \\
\hline 10 & 0.17 & 164.0 & 836.37 & 0.030 & 0.039 & 235.0 & Adequate \\
\hline 11 & 0.50 & 382.0 & 1712.0 & 0.150 & 0.095 & 92.4 & Adequate \\
\hline 12 & 0.50 & 267.0 & 1131.0 & 0.162 & 0.057 & 157.9 & Adequate \\
\hline 13 & 0.30 & 234.0 & 1065.0 & 0.111 & 0.067 & 170.4 & Başarısız \\
\hline 14 & 0.84 & 457.0 & 1770.11 & 0.359 & 0.113 & 82.7 & Adequate \\
\hline 15 & 0.50 & 360.0 & 1460.99 & 0.300 & 0.079 & 133.1 & Adequate \\
\hline 16 & 0.80 & 475.0 & 1827.47 & 0.380 & 0.134 & 73.3 & Adequate \\
\hline 17 & 0.50 & 386.0 & 1541.0 & 0.260 & 0.095 & 119.6 & Adequate \\
\hline 18 & 0.50 & 266.0 & 1161.43 & 0.162 & 0.065 & 182.0 & Adequate \\
\hline 19 & 1.00 & 361.0 & 1464.0 & 0.305 & 0.083 & 132.6 & Adequate \\
\hline 20 & 1.10 & 390.0 & 1555.0 & 0.330 & 0.092 & 117.5 & Adequate \\
\hline
\end{tabular}

Table 9 Test results of ultra lightweight concrete specimens produced with different size expanded perlite aggregates

\begin{tabular}{|c|c|c|c|c|c|c|c|}
\hline $\begin{array}{l}\text { Experiment } \\
\text { Number }\end{array}$ & $\begin{array}{l}\text { Compressive } \\
\text { Strength }(\mathrm{MPa})\end{array}$ & $\begin{array}{c}\text { Dry Unit } \\
\text { Weight }\left(\mathrm{kg} / \mathrm{m}^{3}\right)\end{array}$ & $\begin{array}{l}\text { Ultrasonic Pulse } \\
\text { Velocity }(\mathrm{m} / \mathrm{s})\end{array}$ & $\begin{array}{c}\text { Flexural } \\
\text { Strength }(\mathrm{MPa})\end{array}$ & $\begin{array}{l}\text { Thermal Conductivity } \\
\qquad(\mathrm{W} / \mathrm{mK})\end{array}$ & $\begin{array}{c}\text { Water } \\
\text { Absorption (\%) }\end{array}$ & $\begin{array}{c}\text { Freeze-Thaw } \\
\text { Resistance }\end{array}$ \\
\hline 21 & 0.65 & 313.5 & 1529 & 0.348 & 0.085 & 110 & Adequate \\
\hline 22 & 0.41 & 251.7 & 1220 & 0.273 & 0.062 & 170 & Adequate \\
\hline 23 & 0.64 & 251.8 & 1229 & 0.384 & 0.062 & 167 & Adequate \\
\hline 24 & 1.33 & 357.4 & 1541 & 0.745 & 0.100 & 96 & Adequate \\
\hline 25 & 0.45 & 283.4 & 1276 & 0.324 & 0.084 & 149 & Adequate \\
\hline 26 & 0.58 & 284.7 & 1495 & 0.253 & 0.081 & 147 & Adequate \\
\hline 27 & 0.61 & 292.5 & 1441 & 0.333 & 0.087 & 144 & Adequate \\
\hline 28 & 0.56 & 275.1 & 1431 & 0.186 & 0.078 & 134 & Adequate \\
\hline 29 & 0.32 & 264.4 & 1221 & 0.267 & 0.084 & 151 & Adequate \\
\hline 30 & 0.38 & 235.4 & 1344 & 0.330 & 0.058 & 136 & Adequate \\
\hline 31 & 0.58 & 255.1 & 1441 & 0.189 & 0.059 & 140 & Adequate \\
\hline 32 & 0.37 & 247.0 & 1229 & 0.132 & 0.062 & 154 & Adequate \\
\hline 37 & 0.68 & 217.3 & 1106 & 0.270 & 0.059 & 81 & Adequate \\
\hline
\end{tabular}




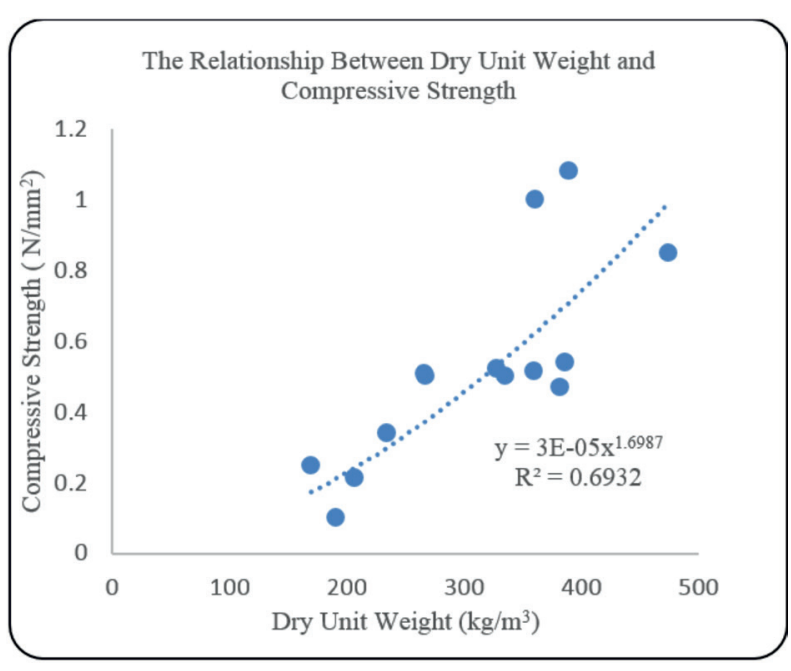

Fig. 11 The relationship between dry unit weight and compressive strength of ULWC specimens produced with P05 aggregate.

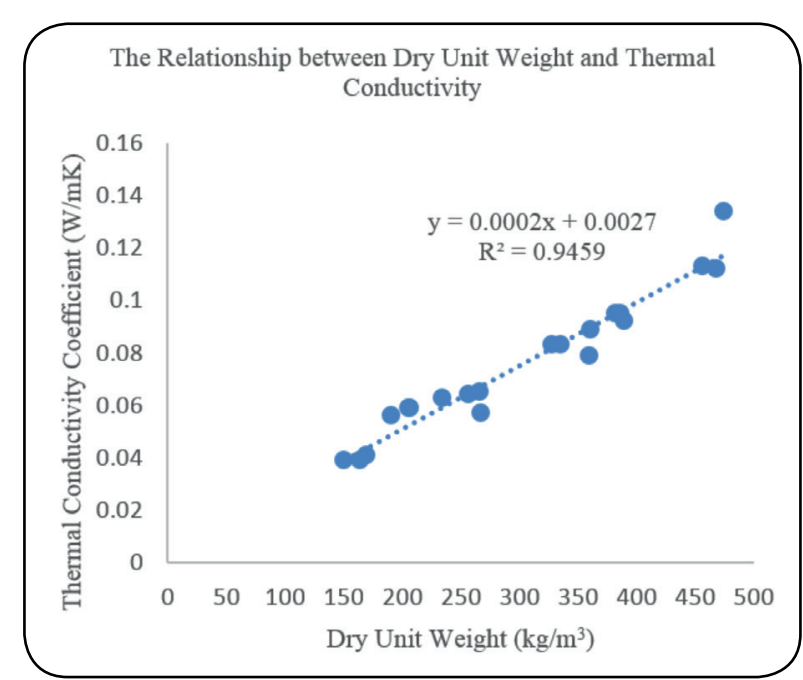

Fig. 12 The relationship between dry unit weight and thermal conductivity coefficient of ULWC specimens produced with P05 aggregate.

The Relationship Between Aggregate Particle Size and Dry Unit Weight

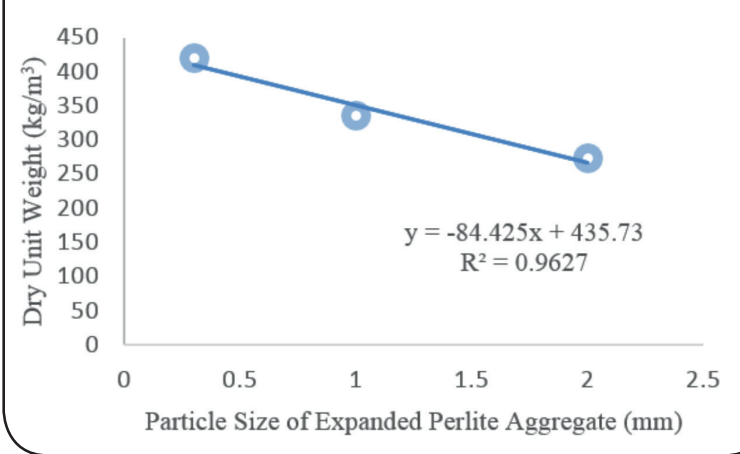

Fig. 13 The effect of different particle size expanded perlite aggregates on the dry unit weight of ULWC specimens.
Table 10 The aggregate particle size distribution, unit weight and water absorption characteristics of the ULWC specimens prepared using different particle size expanded perlite aggregates

\begin{tabular}{|c|c|c|c|c|c|c|}
\hline 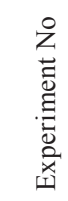 & 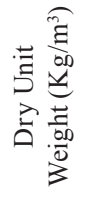 & 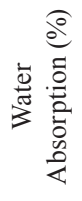 & 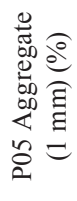 & 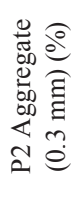 & 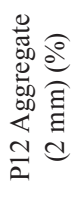 & 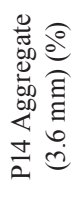 \\
\hline 23 & 273.6 & 167.3 & & & 0.5 & 0.5 \\
\hline 24 & 357.4 & 95.9 & & 0.5 & & 0.5 \\
\hline 25 & 335.0 & 149.4 & 0.5 & & & 0.5 \\
\hline
\end{tabular}

\subsection{The relationship between dry unit weight and thermal conductivity of ULWC specimens produced with P05 aggregate}

The relationship between the dry unit volume weight and the thermal conductivity coefficient of ULWC specimens is given in Fig. 12.

As seen in this graph, there is a correct and meaningful relationship between the thermal conductivity coefficient and dry unit volume weight of ULWC specimens produced with $\mathrm{P} 05$ aggregate $\left(\mathrm{R}^{2}\right.$ value obtained was found to be close to 1). This finding is in good agreement with previous research [17]. In this sense, the thermal conductivity coefficient of the ULWC specimens produced with P05 aggregate with known dry unit volume weight can be determined by using this empirical formula obtained from this relationship and shown on the graph (for dry unit volume range of $\left.150 \mathrm{~kg} / \mathrm{m}^{3}-468 \mathrm{~kg} / \mathrm{m}^{3}\right)$.

\subsection{The effect of expanded perlite aggregate size} distribution on the dry unit weight of ULWC specimens In order to determine the relationship between the expanded perlite aggregate particle size and the unit weight of the ULWC specimens, the experiments in Table 10 were carried out. During these experiments, the most suitable gradation was achieved by taking $50 \%$ of the expanded perlite aggregate with the P14 size. For this purpose, P12, P05 and P2 expanded perlite aggregates, which have smaller grain diameters in different ratios, were used respectively, while the P14 expanded perlite aggregate amount having the maximum particle diameter was kept constant. As shown in Fig. 13, the density of ultra lightweight concrete specimens increase with decreasing particle diameter of expanded perlite aggregate. SEM analysis of the test specimens obtained using only P05 expanded perlite aggregate showed that the void size was small and the distributions were not homogeneous (Fig. 14). SEM analysis results 


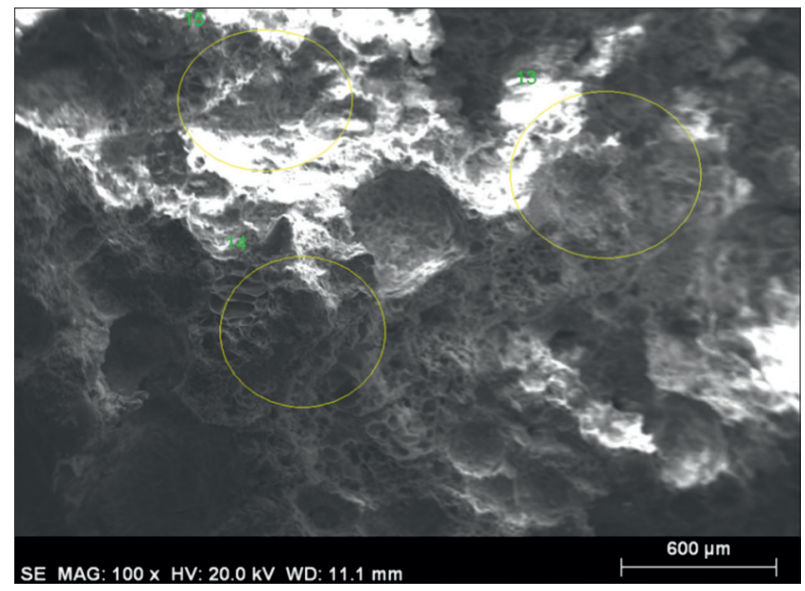

Fig. 14 SEM image of ULWC specimen produced with P05 expanded perlite aggregate

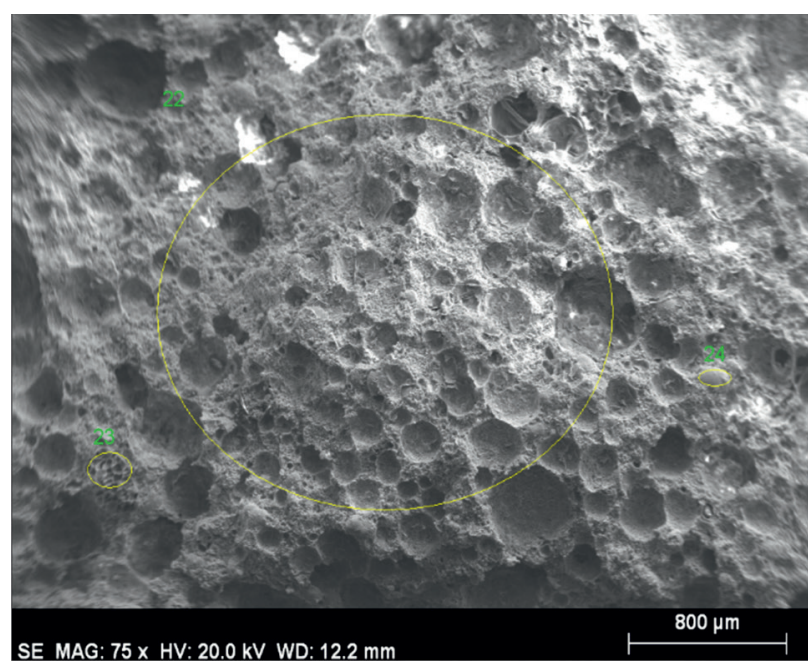

Fig. 15 SEM image of ULWC specimen produced with different size expanded perlite aggregate

of test specimens obtained by using expanded perlite aggregates with different aggregate grain sizes showed larger and homogeneous distribution of void structure (Fig. 15). The void structure of the samples with large particle size diameter is found to be more homogenous and bigger. When the particle size of the expanded perlite aggregate decreases, the void ratio decreases and the homogeneity of the void structure decreases as well. On the other hand, as the expanded perlite aggregate particle size diameter increases, the water absorption percentage increases as well due to the increase of the entrained air in the concrete.

\subsection{Effect of Polypropylene Fibers on the Fresh Properties of ULWC specimens}

Firstly, ultra lightweight concrete specimen with a fiber volume fraction of $0.14 \%$ was prepared. A serious decrease in the volume of the fresh concrete in the mold during settling process was observed. The reason for such a settlement of fresh concrete can be attributed to the gradual disappearance of air bubbles in ultra lightweight concrete by the fibers. In order to solve this problem, the amount of fiber used decreased gradually and with a fiber volume fraction of $0.011 \%$, no decrease in the volume of the fresh concrete was observed (Fig. 16).

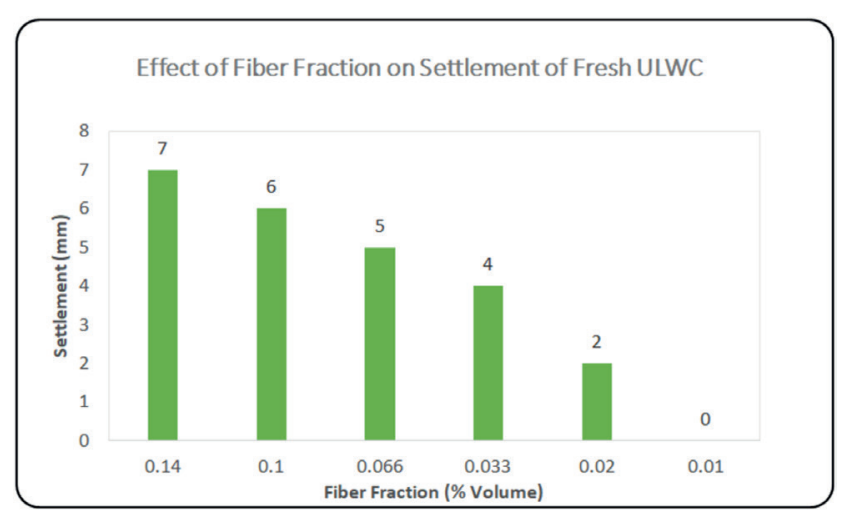

Fig. 16 Effect of fiber volume fraction on the settlement of fresh ULWC specimens

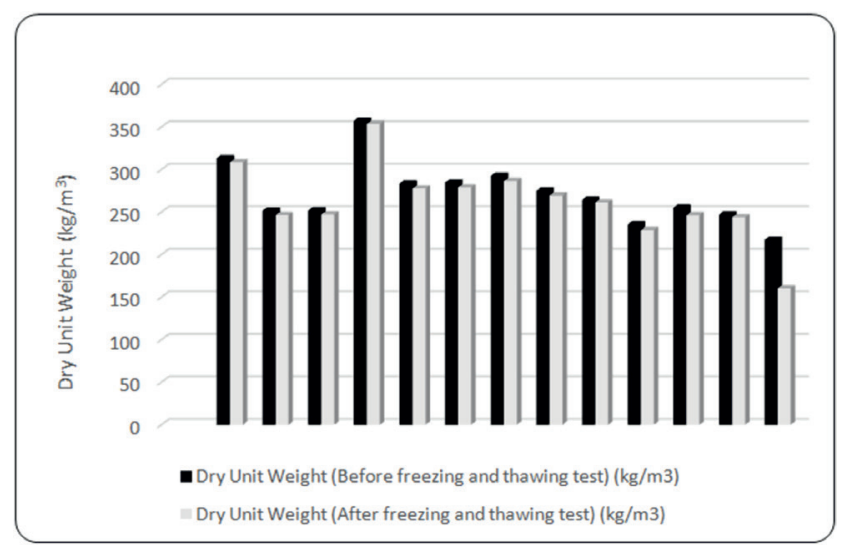

Fig. 17 Mass loss after freezing and thawing cycles

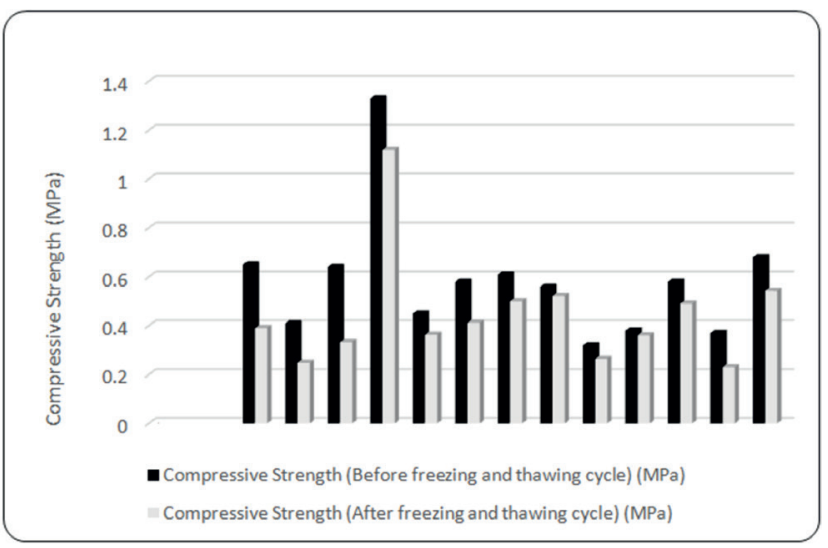

Fig. 18 Effect of freezing and thawing cycles on compressive strength of ULWC specimens 


\subsection{Effect of freezing and thawing cycles on mass loss and compressive strength of ULWC specimens}

The effect of freezing and thawing cycles on mass loss and compressive strength of ultra lightweight concrete specimens prepared with different particle size of expanded perlite aggregates are shown in Fig. 17 and Fig. 18. The mass losses were found to be $1.18 \%-3.44 \%$ whereas the compressive strengths decreased $5 \%-47 \%$.

\section{Summary and conclusions}

The present research is aimed at developing an economically and environmentally viable ultra lightweight concrete while improving the mechanical and thermal properties (with very low thermal conductivity and reasonable strength) of ultra lightweight concrete. Therefore, in this study, a detailed experimental program was conducted to develop ULWC specimens using different size of expanded perlite aggregates. The developed ULWC could be a practical solution for economical and sustainable structures due to its excellent thermal properties with reasonable mechanical strength and superior durability properties. Based on the results obtained, the thermal conductivity coefficient of ULWC specimens was observed to decrease with a decrease in dry unit weight. It has been found that, the ultra lightweight concrete samples produced with expanded perlite aggregate with a dry unit weight of $150 \mathrm{~kg} / \mathrm{m}^{3}$ or less have a thermal conductivity coefficient less than $0.040 \mathrm{~W} /$ $\mathrm{mK}$, compressive strength of $0.13 \mathrm{MPa}$ and a water absorption percentage of $242.3 \%$. It has been observed that the decrease in the dry unit volume weight leads to an increase in the water absorption percentage while reducing the compressive strength as well. On the other hand, the compressive strength is expected to decrease as the concrete specimens absorb water and become wet. But simple measures (i.e. water repellent paints etc.) can be taken to make the ULWC specimens watertight.

Within the scope of this study, the effect of the amount of the air entraining admixture on the dry unit weight of

\section{References}

[1] Kilıç, A., Atiş, C. D., Yaşar, E. Özcan, F. "High-strength lightweigth concrete made with scoria aggregate containing mineral admixture", Cement and Concrete Research, 33(10), pp. 1595-1599, 2003. https://doi.org/10.1016/S0008-8846(03)00131-5

[2] Sengul, O., Azizi, S., Karaosmanoglu, F., Tasdemir, M. A. "Effect of expanded perlite on the mechanical properties and thermal conductivity of lightweight concrete", Energy and Buildings, 43(2-3), pp. 671-676, 2008.

https://doi.org/10.1016/j.enbuild.2010.11.008 ultra lightweight concrete has been examined and it was found that, as the amount of air-entraining admixture used in the test samples increased, its effect on decreasing the dry unit weight of ultra lightweight concrete samples becomes ineffective. In this respect, it has been determined that the use of air entraining admixture in excess of $4.5 \mathrm{~kg}$ per cubic meter reduces the effect of unit volume weight and becomes uneconomical.

The amount of fibers used in ULWC concretes was found to directly affect the settlement of fresh concretes due to the gradual disappearance of air bubbles in ultra lightweight concrete by the fibers. A fiber volume fraction of $0.011 \%$ is proposed to be used in order not to have any settlement in the volume of the fresh ultra lightweight concretes.

The effect of freezing and thawing cycles on mass loss and compressive strength of ultra lightweight concrete specimens prepared with different particle size of expanded perlite aggregates was found to be between $1 \%-3.5 \%$ and $5 \%-47 \%$, respectively.

Finally, SEM analysis of the test specimens showed that by using expanded perlite aggregates with different aggregate particle sizes the dry unit weight of ULWC samples can be decreased due to larger and homogeneous distribution of void structure.

The results of this study shows the practical impact of using expanded perlite aggregates in the production of ultra lightweight concrete building materials. Lower thermal conductivity coefficients of ultra lightweight concrete produced with expanded perlite aggregates would offer important economic and environmental benefits with using ULWC blocks for construction of non-load bearing exterior walls.

\section{Acknowledgement}

This study was fully supported by Turkish National Science Foundation (Grant Number: TUBITAK 115M037). The authors gratefully acknowledge the financial support by Turkish National Science Foundation.

[3] Akınc1, H. "Today's Thermal Insulation Materials Applied, Their Properties, Application Techniques and Cost Analysts", Master of Science Thesis, Sakarya University, 2007. (in Turkish)

[4] Demirboğa, R., Örüng, I., Gül, R. "Effects of expanded perlite aggregate and mineral admixtures on the compressive strength of low-density concretes", Cement and Concrete Research, 31(11), pp. 1627-1632, 2001. https://doi.org/10.1016/S0008-8846(01)00615-9 
[5] Kalaycı, F. "The production of perlite based isolation material", Master of Science Thesis, Kahramanmaraş Sütçü İmam University, 2016. (in Turkish)

[6] Öztürk, M. "Examining physical and mechanical properties of lightweight concrete with pumice and perlite", Master of Science Thesis, Tekirdağ Namık Kemal University, 2012. (in Turkish)

[7] Demirboğa, R., Gül, R. "The effects of expanded perlite aggregate, silica fume and fly ash on the thermal conductivity of light weight concrete", Cement and Concrete Research, 33(5), pp.723-727, 2003. https://doi.org/10.1016/S0008-8846(02)01032-3

[8] Torres, M. L., García-Ruiz, P. A. "Lightweight pozzolanic materials used in mortars: Evaluation of their influence on density, mechanical strength and water absorption", Cement and Concrete Composites, 31(2), pp. 114-119, 2009.

https://doi.org/10.1016/j.cemconcomp.2008.11.003

[9] Fenyvesi, O. "Affect of lightweight aggregate to early age cracking in concrete", Periodica Polytechnica Civil Engineering, 55(1), pp. 63-71, 2011.

https://doi.org/10.3311/pp.ci.2011-1.08

[10] Balendran, R. V., Zhou, F. P., Nadeem, A., Leung, A. Y. T. "Influence of steel fibres on strength and ductility of normal and lightweight high strength concrete", Building and Environment, 37(12), pp. 1361-1367, 2002.

https://doi.org/10.1016/S0360-1323(01)00109-3
[11] Chen, B., Liu, J. "Contribution of hybrid fibers on the properties of high-strength lightweight concrete having good workability", Cement and Concrete Research, 35(5), pp. 913-917, 2005. https://doi.org/10.1016/j.cemconres.2004.07.035

[12] ASTM "ASTM C642-13 Standard Test Method for Density, Absorption, and Voids in Hardened Concrete", ASTM International, West Conshohocken, PA, USA, 2013.

[13] ASTM "ASTM C495 Standard Test Method for Compressive Strength of Lightweight Insulating Concrete", ASTM International, West Conshohocken, PA, USA, 2012.

[14] ASTM "ASTM C78 Standard Test Method for Flexural Strength of Concrete (Using Simple Beam with Third-Point Loading)", ASTM International, West Conshohocken, PA, USA, 2018.

[15] TSE "TS EN 15304 Determination of the freeze-thaw resistance of autoclaved aerated concrete", Turkish Standards Institute, Ankara, Turkey, 2010.

[16] TSE "TS EN 12667 Thermal performance of building materials and products - Determination of thermal resistance by means of guarded hot plate and heat flow meter methods - Products of high and medium thermal resistance", Turkish Standards Institute, Ankara, Turkey, 2003

[17] Yıldırım, M. Ş., Biçer, Y., Yıldız, C. "An investigation on physical properties of styropor concretes as insulation materials", presented at 9th National Congress of Heat Science and Technique, Elazı̆̆, Turkey, Sept. 20-22, 1993. (in Turkish) 